\title{
Establish Fuel Qualification Expectations
}

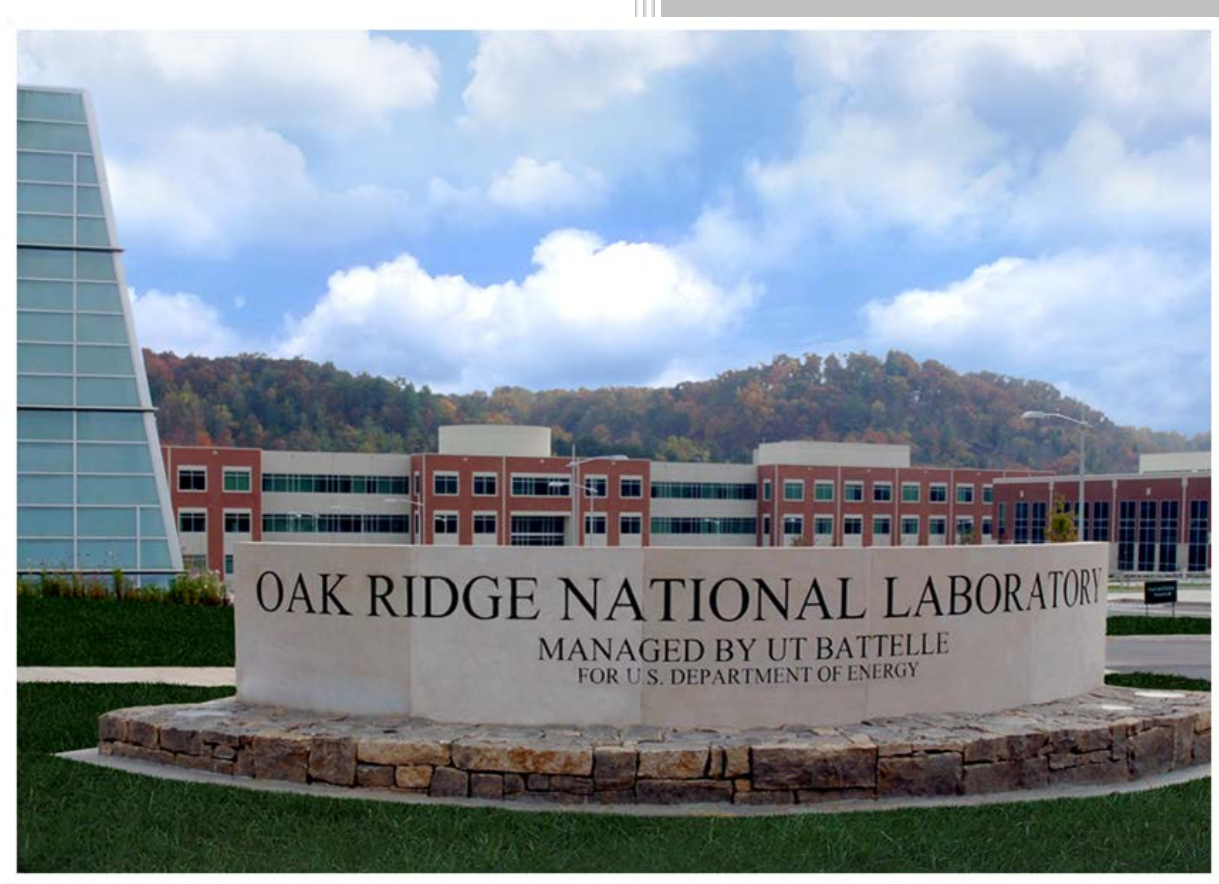

Approved for public release.

Distribution is unlimited.

G. F. Flanagan

A. L. Qualls

April 2018 


\title{
DOCUMENT AVAILABILITY
}

Reports produced after January 1, 1996, are generally available free via US Department of Energy (DOE) SciTech Connect.

\section{Website www.osti.gov}

Reports produced before January 1, 1996, may be purchased by members of the public from the following source:

\author{
National Technical Information Service \\ 5285 Port Royal Road \\ Springfield, VA 22161 \\ Telephone 703-605-6000 (1-800-553-6847) \\ TDD 703-487-4639 \\ Fax 703-605-6900 \\ E-mail info@ntis.gov \\ Website http://classic.ntis.gov/
}

Reports are available to DOE employees, DOE contractors, Energy Technology Data Exchange representatives, and International Nuclear Information System representatives from the following source:

Office of Scientific and Technical Information

PO Box 62

Oak Ridge, TN 37831

Telephone 865-576-8401

Fax 865-576-5728

E-mail reports@osti.gov

Website http://www.osti.gov/contact.html

This report was prepared as an account of work sponsored by an agency of the United States Government. Neither the United States Government nor any agency thereof, nor any of their employees, makes any warranty, express or implied, or assumes any legal liability or responsibility for the accuracy, completeness, or usefulness of any information, apparatus, product, or process disclosed, or represents that its use would not infringe privately owned rights. Reference herein to any specific commercial product, process, or service by trade name, trademark, manufacturer, or otherwise, does not necessarily constitute or imply its endorsement, recommendation, or favoring by the United States Government or any agency thereof. The views and opinions of authors expressed herein do not necessarily state or reflect those of the United States Government or any agency thereof. 
Reactor and Nuclear Systems Division

\title{
ESTABLISH FUEL QUALIFICATION EXPECTATIONS
}

\author{
George F. Flanagan \\ A. Lou Qualls
}

Date Published: April 2018

Prepared by

OAK RIDGE NATIONAL LABORATORY

Oak Ridge, TN 37831-6283

managed by

UT-BATTELLE, LLC

for the

US DEPARTMENT OF ENERGY

under contract DE-AC05-00OR22725 



\section{CONTENTS}

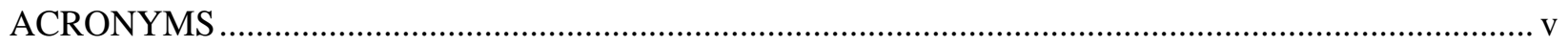

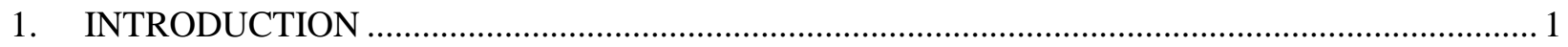

2. HISTORICAL LIGHT WATER REACTOR FUEL QUALIFICATION ....................................... 1

3. REGULATORY EXPECTATIONS ON LWR FUEL QUALIFICATION ...................................... 2

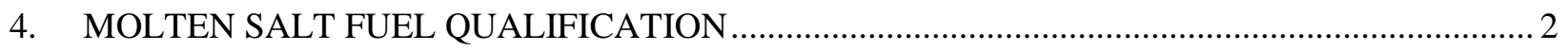

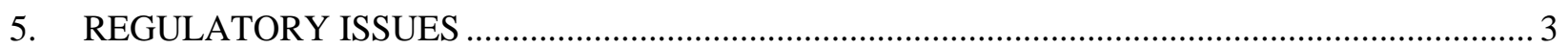

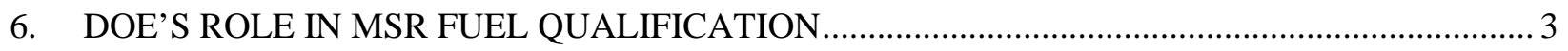

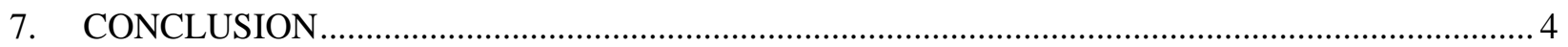





\section{ACRONYMS}

$\begin{array}{ll}\text { DOE } & \text { US Department of Energy } \\ \text { FAST } & \text { Fuel Analysis under Steady-state and Transients } \\ \text { LWR } & \text { light water reactor } \\ \text { MOX } & \text { mixed oxide (fuel) } \\ \text { MSR } & \text { molten salt reactor } \\ \text { NRC } & \text { US Nuclear Regulatory Commission } \\ \text { ORNL } & \text { Oak Ridge National Laboratory } \\ \text { R\&D } & \text { research and development } \\ \text { TREAT } & \text { Transient Reactor Test (facility) } \\ \text { TRISO } & \text { tri-structural-isotropic (fuel) }\end{array}$





\section{INTRODUCTION}

The objective of this white paper is to provide an overview of the state of knowledge regarding issues associated with fuel qualification for a liquid-fueled molten salt reactor. The overview consists of fuel qualification expectations for heterogeneous reactors - conventional light water reactors, plus advanced reactors such as sodium fast reactors and modular high-temperature gascooled reactors - which consider the mechanical behavior of the fuel itself, interaction between fuel and its cladding, behavior of the cladding, and structural behavior of fuel assemblies. Fuel qualification expectations for molten salt reactors are viewed in contrast to the fuel qualification for heterogeneous reactors in that the fuel is liquid (molten) and there is no accumulation of mechanical effects such as stress, creep, or swelling. However, the liquid fuel salts do accumulate fission products, corrosion byproducts, and buildup of actinides which impact the chemistry of the fuel salt and thermal-physical properties that may impact the ability to remove heat from the core and retain radioactive materials in the fuel salt. Finally, the role of the US Department of Energy in research on tri-structural-isotropic and metal fuel for advanced reactors for fuel qualification purposes is briefly discussed as a potential model for the Department's research to gather quality chemical and thermal-physical property data necessary to qualify MSR fuel performance under normal and accident conditions.

\section{HISTORICAL LIGHT WATER REACTOR FUEL QUALIFICATION}

For heterogeneous reactor systems such as light water reactors (LWRs), the fuel/cladding system is the principal barrier to prevent the release of fission products. As such, it is important to the design and safety of any reactor to ensure that the behavior of this system is understood for all operational conditions: normal conditions, anticipated transient conditions, postulated accidents, and conditions beyond design basis events. It is also important to ensure a clear understanding of how fabrication, transportation, and storage impact the fuel/cladding system. This analytical process is referred to as fuel qualification.

Extensive effort has been focused on understanding this important function. Fuel performance codes have been developed to predict the behavior of fuel and its surrounding cladding. The information captured in these codes includes (1) the mechanical behavior of the fuel itself, especially as it is affected by temperature and irradiation, including the resulting buildup of fission products and fission gases, swelling, and structural integrity; (2) the interaction between the fuel and its cladding, including the closure of the gap between the fuel and cladding due to fuel swelling; (3) the behavior of the cladding, including mechanical damage such a blistering, buckling, and chemical behavior such as corrosion and crud build up; and (4) the structural behavior of the fuel assembly which may be affected by external events such as seismic or severe environments that may occur during a large break loss-of-coolant accident.

The data, which are the basis for these performance codes, are based on experience gleaned from separate effects testing, integrated effects testing, test reactors, lead test assemblies, and operational experience from existing power plants. The data are basic to fuel qualification, and recent experience has shown that when new types of fuel are introduced, it may take several years and millions of dollars to collect the data on fuel qualification that are needed to assure its quality. Many of these effects (mechanical, temperature, and irradiation) are accumulated over 
the history of the fuel while it is in the reactor core. Therefore, long-term irradiation, followed by extensive post-irradiation examination, are required to obtain these data.

\section{REGULATORY EXPECTATIONS ON LWR FUEL QUALIFICATION}

There is no single regulatory guide that indicates regulatory expectations regarding LWR fuel qualification. However, 10 CFR 50.45 contains information on peak cladding temperature, oxidation rates, and structural requirements during and following a larger break loss-of-coolant accident. Other important regulatory documents addressing fuel behavior include the US Nuclear Regulatory Commission (NRC) Standard Review Plan for the Review of Safety Analysis Reports for Nuclear Power Plants: LWR Edition (NUREG 0800), Chapter 4.2, "Fuel," and Regulatory Guide 1.206, Combined Licensing Applications, Chapter 4.2, “Fuel.” Fuel qualification data are also used in the NRC Fuel Analysis under Steady-state and Transients (FAST) confirmatory fuel performance code.

In addition, several documents related to recent fuel qualification programs have been developed. These include a draft project plan to prepare the NRC to license and regulate accident-tolerant fuel, a fuel qualification plan for mixed oxide (MOX) fuel, and ORNL/TM-13406, Fuel Qualification Issues and Strategies for Reactor-based Surplus Plutonium Disposition.

\section{MOLTEN SALT FUEL QUALIFICATION}

Molten salt fueled reactors are unique in that since the fuel is liquid, there is no accumulation of mechanical effects such as stress, creep, or swelling. The fluoride-based salts data from experiments and during operation of the Molten Salt Reactor Experiment indicated that, although there are local impacts (molecular level) on the chemical behavior of the fuel salt resulting from the energetics of the fission process, because the fuel is in a liquid state, these are not accumulated and have little or no impact on the fuel salt itself. For chloride-based salts, there is no such database, although it is expected that they would behave in a similar manner. Thus, irradiation behavior is unlikely to play as major a role for molten salt reactor (MSR) fuel as for LWR fuel. However, chemical species accumulate in the fuel salt due to the creation and decay of fission products, corrosion of materials, and buildup of actinides. These factors must be considered and well understood because they will impact the chemistry of the fuel salt. The fuel salt is also the coolant in an MSR, so changes in its chemical composition resulting from the creation of fission products and corrosion products will also impact thermal-physical properties such as melting point, thermal heat capacity, thermal conductivity, viscosity, and density. Changes in these properties may in turn impact the ability to remove heat from the core. Furthermore, chemical property changes may impact the retention of some radioactive materials in the salt, resulting in source term implications.

Thus, the fuel qualification process developed for LWRs is unlikely to be of use for MSR fuel qualification. The MSR fuel qualification centers around understanding the chemical behavior of the fuel, fission products, corrosion products, and actinides, including thermal hydraulics implications, rather than developing an understanding of the mechanical and irradiation behavior of solid materials under normal and accident conditions. 


\section{REGULATORY ISSUES}

There is no regulatory position specifically related to MSR fuel qualification. However, in recent presentations made at the NRC advanced reactor stakeholders meeting (August 2017), the NRC provided the following advanced reactor fuel qualification definition statement for use by advanced reactor design organizations:

"Fuel qualification is a process which provides high confidence that physical and chemical behavior of fuel is sufficiently understood so that it can be adequately modeled for both normal and accident conditions, reflecting the role of the fuel design in the overall safety of the facility. Uncertainties are understood such that any calculated fission product releases include appropriate margin to ensure conservative calculation of radiological dose consequences"

Based on this definition, the NRC has asked Oak Ridge National Laboratory to develop a white paper describing the unique issues related to MSR fuel qualification. This paper will also address coupling fuel qualification with thermal hydraulics analysis (decay heat removal and normal heat removal), and modeling fission product retention, during normal and accident conditions. A process will be proposed to (1) address how sensitivities and uncertainties are taken into account to ensure that a conservative margin is achieved in the calculation of radiological consequences, and (2) find a method to determine the important properties that must be measured and the conditions under which they should be measured. Currently the white paper is in development, but it has not yet been vetted with the NRC.

\section{DOE'S ROLE IN MSR FUEL QUALIFICATION}

For gas and liquid metal reactors, the US Department of Energy (DOE) has played a major role in developing a quality database for tri-structural-isotropic (TRISO) and metal fuel. This database is used to develop fuel performance codes for use by the industry and serves as the basis for confirmatory fuel performance codes within the NRC. This data collection includes extensive irradiation in the DOE reactors, post-irradiation examination in DOE hot cells, and transient testing in the Transient Reactor Test (TREAT) facility. Assuming that DOE will also play a similar role in development of MSR technologies, it is important that NRC specify their expectations as to what fuel qualification means for the MSR technology. Once the NRC's expectations are defined, then DOE can institute a research and development (R\&D) effort to gather the requisite quality data using their infrastructure and resources to support MSR concepts in a manner similar to what was done for other advanced reactor technologies. In addition to data, it is likely that new MSR fuel performance codes will need to be developed to incorporate thermal physical property models in a manner similar to that implemented for the current LWR

fuel performance codes to incorporate irradiation damage models. Safety analysis tools must also be developed that appropriately incorporate the fuel performance codes to assess the adequacy of MSR cooling systems under normal and accident conditions. Finally, fuel qualification data will be required to develop mechanistic source terms for MSRs. 


\section{CONCLUSION}

Fuel qualification for MSRs is a major factor in the design and licensing of any future MSR. This initiative will not only address fuel behavior for normal and accident conditions, but it will also have a major impact on the ability to cool the core and the mechanistic source term. The DOE R\&D effort must be aligned with the NRC's expectations for fuel qualification. 